Trinity University

Digital Commons @ Trinity

English Faculty Research

English Department

Fall 2012

\title{
George Saunders and the Postmodern Working Class
}

David Rando

Trinity University, drando@trinity.edu

Follow this and additional works at: https://digitalcommons.trinity.edu/eng_faculty

Part of the English Language and Literature Commons

\section{Repository Citation}

Rando, D.P. (2012). George Saunders and the postmodern working class. Contemporary Literature, 53(3), 437-460. doi: 10.1353/ cli.2012.0024

This Post-Print is brought to you for free and open access by the English Department at Digital Commons @ Trinity. It has been accepted for inclusion in English Faculty Research by an authorized administrator of Digital Commons@ Trinity. For more information, please contact jcostanz@trinity.edu. 


\title{
[This is the "working paper" version of an article later published as: "George Saunders and the Postmodern Working Class.” Contemporary Literature 53.3 (Fall 2012): 437-60. Please refer to the final published version for purposes of citation.]
}

\author{
David P. Rando \\ Trinity University
}

George Saunders and the Postmodern Working Class

George Saunders peoples his stories with the losers of American history - the dispossessed, the oppressed, or merely those whom history's winners have walked all over on their paths to glory, fame, or terrific wealth. Among other forms of marginalization, Saunders's subject is above all the American working class. In the last twenty or more years, however, for reasons that include the fall of the Soviet Union, the impact of poststructuralist theory, conceptualizations of identity that more and more take race and gender into consideration alongside class, and the general cultural turn in class analysis, it has become increasingly difficult to write about class and unclear what value the "working class" has as a concept for social and cultural analysis or for literary representation. Saunders's fiction not only reflects these changed ways of conceiving class but also challenges us to reconsider basic questions of class representation. "Sea Oak," from Pastoralia (2000), is perhaps the most effective expression of Saunders's class constructions and representative of his approach to the formal representation of class. "Sea Oak" attempts to represent the realities of class in an era when the concept has lost its objective determination and has become one coordinate in a differential field of experience and identity that includes race, gender, sexuality, and culture. Moreover, while constructing working-class identity as a complex, differential field, "Sea Oak" intervenes in enduring debates concerning literary form and working-class representation. Subscribing wholly to neither tradition nor avant-gardism, "Sea Oak" provocatively suspends the techniques of realism and postmodernism in tense differential relation. This suspension creates productive incongruities that allow Saunders's fiction to undermine class ontologies, often through powerfully affective moments of formal collision.

While few still privilege social class in ways traditionally encouraged by strict economic determinism, critics have fruitfully built upon E. P. Thompson's well-known definition of class as "a relationship, not a thing" (11). As Wai Chee Dimock and Michael T. Gilmore describe, critics now "entertain a range of interactive relations - class and culture, class and race, class and gender - without making causality a one-directional phenomenon, and without attributing to the first term a determinative weight" (3). The result has not only established class as a complex "differential field" but may also expose "varying relays between the economic and the social, and therefore also with multiple points of action, and multiple registers of experiential effect" (8). "Class has been queered," Cora Kaplan observes, because "[i]ts desires, its object choices, and its antagonisms are neither so straightforward nor so singular as they once seemed" (13). If class as a concept has lost its objective appearance and fixed structure, it has gained by becoming a differential coordinate in a system of human relations that also considers other key contributors to identity. One result, Dimock and Gilmore imply, is that class is acknowledged to be a relationship both complex and complexly experienced.

This conceptual shift raises with new urgency the question of representation. How can class as a differential field find critical or literary expression? How can class be represented as a crucial, but by no means solely determinant, dimension of individual or collective experience? Such challenges, moreover, revivify old but enduring questions about literary form and class representation. In the late 1920s and early 1930s, Soviet critics and other Communist Party 
members debated the relation between literary form and efficacious working-class representation. Could realism, a literary form inherited from the bourgeois novel, be appropriated for workingclass representation, or was it finally compromised by its bourgeois origins and individualist conventions? Could literary experimentation or avant-gardism help to shatter the conventions of realism and effectively represent working-class concerns, or did experimental techniques fail to fully represent people as "social animals," as Georg Lukács accused modernism of neglecting to do (19)?

More recently, this debate has been extended in certain poststructuralist critiques of realism. Barbara Foley concedes to a common poststructuralist view of realism:

[T] he tendency of realistic narrative to dissolve contradiction in the movement toward closure; its characteristic opposition of the social to the personal, and its displacement of social critique onto personal ethical choice; its insistence upon the uniqueness, and often the superiority, of its protagonist(s); its co-optation of the reader into agreement with the discourse occupying the apex of the text's implied hierarchy of discourses - these defining features of novelistic realism can indeed undermine, if not cancel out, the proletarian novel's espoused political commitments. (261)

However, Foley compellingly argues that literary form should be approached not as deterministic but as a "tendency," which "is best understood ... as the intersection of generic politics with doctrinal politics" (262). In other words, the politics of form, though perhaps tending ideologically in one direction or another, always interacts with the politics of content in ways that cannot be determined beforehand. As they say in baseball, that's why you play the games; so in fiction, that's why you write the stories. In addition to opening up possibilities within realist form for representing working-class concerns, Foley's approach also cautions against the tendency to privilege avant-gardism by reflexively associating it with counterhegemony. Likewise, Pamela Fox argues, "Preserving avant-gardism as the privileged term and conceiving of resistance as a primarily discursive activity, poststructuralist theory can misidentify the cultural resources available to working-class writers and misread the very issues in question" (22). Saunders is similarly cautious in his use of both realist and postmodernist techniques, well aware of their various formal tendencies and shortcomings for representing the complexity of class identities but playing them off of one another, to disruptive and often virtuosic effect.

"Sea Oak" tells the story of a few peculiar weeks in the life of a working-class family. The climactic event occurs when a burglar breaks into the family's apartment and quite literally scares the aunt, Bernie, to death. The story not only purports to represent a working-class family but is also deeply and reflexively aware of its inability to articulate that family's experiences and its own peculiar hauntedness. The limits of the story's own largely realistic representational strategy require a major intervention, powerfully manifested when the hitherto realist, satirical, and grotesque-comic discourse of the story is interrupted by Aunt Bernie's startling return from the dead. Using the terms of Brian McHale's useful distinction between the dominants of modernism and postmodernism, we could say that Aunt Bernie's resurrection constitutes a postmodernist intervention in the prevailing discourse of the story because it foregrounds crucial new questions of ontology: can this resurrection be real? ${ }^{1}$ Did Aunt Bernie really just return from the dead? In what kind of world can such things occur?

But the ontological questions pile up and spiral wider. They begin to implicate the middle-class reader whom the narrator seems to address. Saunders suggests that such readers may be so blind to the working class that its experiences are otherworldly: what universe does 
the working class actually inhabit? The narrator suggests:

Maybe it happens all the time. Maybe there's angry dead all over, hiding in rooms, covered with blankets, bossing around their scared, embarrassed relatives.

Because how would we know?

I for sure don't plan on broadcasting this. ("Sea Oak” 123-24)

The early part of "Sea Oak" foregrounds questions of epistemology: in what ways can the working class be represented, given the complexity of this concept in our time? But Bernie's grotesque resurrection turns these epistemological questions on their heads and answers that the unknown, inadequately represented experiences and sufferings of this class may be more elusive and powerful than those that have already been represented. In "Sea Oak," Saunders

demonstrates that one means of representing the working class may be to perform the inadequacy of conventional representations. He models the conventions of realism and satire only to rupture them through a shocking postmodernist intervention that suggests that the deepest experiences of class have hitherto remained hidden. In what follows, I trace "Sea Oak"'s working-class representation through its inextricability from culture, gender, sexuality, and race, as well as through forms of realism and postmodernism that attempt to overcome the "tendencies" of both bourgeois realism and the easy appearance of "resistance" in postmodernism. I conclude with a discussion of how "Sea Oak" complicates what it means to "broadcast" class.

\section{Cultural Ideologies and Class}

"Sea Oak" represents culture as a central dimension of class experience in both its material and ideological forms. Much of Saunders's work seems informed by the tension between the ideological abstractions that govern American culture, on the one hand, and, on the other, the malignant, sad, or simply shabby reality that these abstractions generate for his no-life lowlifes, characters who barely manage to live and labor beneath the weight of ideology and just above the cold, material bottom.

The narrator of "Sea Oak" is a young man who waits tables in his underwear at Joysticks, an aviator-themed adult entertainment club for women. He helps to support his sister, Min, and their cousin, Jade, both single mothers of infant children. They study optimistically (although hopelessly, readers understand) for their General Educational Development, or GED, exams during the commercial breaks of daytime television. They all share an apartment in a community called Sea Oak, though of course, "At Sea Oak there's no sea and no oak, just a hundred subsidized apartments and a rear view of FedEx" (93). Living with the narrator, Min, and Jade is their Aunt Bernie. Bernie's life has been more or less miserable, though the narrator tells us that she compulsively paints a pleasant face on everything and never complains: "But she's not bitter. Sometimes she's so nonbitter it gets on my nerves. When I say Sea Oak's a pit she says she's just glad to have a roof over her head" (95). The narrator always offers realism, or perhaps cynicism, in the face of Bernie's apparent avoidance or self-deceptions: "My feeling is, Bernie, I love you, but where are you? You work at DrugTown for minimum. You're sixty and own nothing. You were basically a slave to your father and never had a date in your life" (98).

Jade, impressed by Bernie's ability to filter out negative experiences, remarks, "Man, what an optometrist" (95). Jade's comic error does not bode well for her chances of obtaining her GED, but it does work in the story as a pun that glosses Bernie's "optimism," suggesting that she "corrects" negative visions of their working-class life through her lens of patience and pleasantness. Saunders shows how other cultural discourses in the story help to maintain and 
reproduce the ideology of patience and pleasantness that Bernie has internalized. For instance, one of the television shows that Min and Jade enjoy watching is How My Child Died Violently. This show appears to exploit the deaths of children and the grief of their parents for sensationalistic value, though exploitation is shielded by the discourses of therapy and compassion. The host, Matt Merton, is "always giving the parents shoulder rubs and telling them they've been sainted by pain" (93). Bernie, too, seems like a kind of long-suffering saint, one who subscribes to the ideology of positive suffering. When there is a shoot-out in the courtyard at Sea Oak and one of the infants' walkers is hit with a bullet, Bernie says: "We should be thankful. At least we got a home. And at least none of them bullets actually hit nobody" (97). Having internalized an ideology of patience and gratitude, Bernie remains reconciled to her job, her living conditions, and her class position.

Aunt Bernie's patience and gratitude is only one of the discourses Saunders satirizes and models in order to show how cultural ideologies help to reconcile characters to their class positions. Another is the myth of American individualism and selfdetermination. Freddie (Min and the narrator's mother's boyfriend) lectures them on the American work ethic and the American dream:

Let me tell you something. ... Something about this country. Anybody can do anything. But first they gotta try. And you guys ain't. Two don't work and one strips naked? I don't consider that trying. You kids make squat. And therefore you live in a dangerous craphole. And what happens in a dangerous craphole? Bad tragic shit. It's the freaking American way - you start out in a dangerous craphole and work hard so you can someday move up to a somewhat less dangerous craphole. And finally maybe you get a mansion. But at this rate you ain't even gonna make it to the somewhat less dangerous craphole. (106)

Freddie's speech amalgamates the myth of the American dream with a coarseness and ungrammaticality that is comic and somewhat grotesque. The thrust of his argument, however, is familiar: if you do not have money, you must not be trying. Freddie says, "it's time for you to pull yourselfs up by the bootstraps" (105). Readers attuned to the ridiculousness of Min's and Jade's situation may feel that Freddie's bootstrap philosophy contains something of potential value, to them at least. However, Saunders couples Freddie's speech with details from Min's and Jade's histories that emphasize their economic paralysis, exerting pressure on Freddie's philosophy from the moment it is evoked. We learn that Min and Jade do not work because they had to quit their jobs at HardwareNiche after they found their daycare provider drunk and "Troy sitting naked on top of the washer and Mac in the yard being nipped by a Pekingese" (105-6).

\section{My Class and My Penile Simulator}

In contrast to Bernie's ideology of patient suffering and Freddie's bootstrap philosophy, the narrator has a more realistic vision of their situation. He is all too aware of the forces that keep him pinned in his class position, which are inseparable from his gendered experiences. "Sea Oak" records with care the intersections of gender and class for Min, Jade, and Bernie, emphasizing how their situations are often doubly oppressive. This is also true for the narrator and his experience of masculinity. Fueled by care, but also by a patriarchal initiative and feelings of masculine responsibility, he desperately wants to move his whole family to Canada, where he feels they would be safe. ${ }^{2}$

Saunders carefully analyzes the humiliations of the narrator's job. In part, this scrutiny 
involves exposing the incongruities of the managerial or euphemistic discourse that adheres to his work and to the act he performs. For instance, the narrator is not said to strip out of a flight uniform and wait on drunken women; rather, he "Pilots" tables (92), a term that obscures rather than clarifies the nature of his labor. Ironically, the simulation he must perform of a manly and heroic aviator tends to emasculate him, another humiliation that Saunders explores. In the course of the story, the narrator agrees to photograph a fellow waiter's buttocks for ten dollars, to oilwrestle another for fifteen dollars, and to hand-feed chicken wings to women at a table for twenty dollars, all for the amusement of the women in higher class positions who form the clientele at Joysticks. The class disparity between the narrator and the women he performs for is nowhere more apparent than when he is called upon to entertain a former girlfriend who dumped him at the end of high school to follow her middle-class dreams of working in an office and owning a Porsche: "No way am I table dancing for Angela Silveri" (117).

One prohibition in his job is that the narrator may not expose his penis under any circumstances, even if the women are willing to pay extra to see it. Instead, he wears a "Penile Simulator," a device that substitutes for his penis and adds another element of ironic dislocation to his labor: "yes, we can show them, we can let them stick out the top of our pants, we can even periodically dampen our tight pants with spray bottles so our Simulators really contour, but our real penises, no, those have to stay inside our hot uncomfortable oversized Simulators" (95-96). Just as the simulated aviators' oversized heroics have an emasculating effect, so the oversized Penile Simulators have a castrating effect. Saunders envisions a form of labor that emasculates the worker through the very performance of his ostensibly masculine work. When men have no institutional or class-privileged means of leveraging power, all that is left to them may be exaggerated masculine sexuality. Even this is denied the narrator; add the other Joysticks prohibition against kissing, and there is little chance for any sensual joy at all within Joysticks' pleasureless dome.

The narrator's emasculation operates in a cultural field of basic assumptions about white male freedom and agency. In order to understand how race figures differentially in "Sea Oak," it is useful to consider another of Saunders's stories, in which race has a greater thematic presence. The narrator of "Christmas" (2003), known to the black roofers on his crew as "The Great White Dope," fails to intervene when one of the most generous and vulnerable of these roofers is manipulated by their white supervisor into gambling his Christmas bonus away. "There comes that phase of life," the narrator later says, "when, tired of losing, you decide to stop losing, then continue losing. Then you decide to really stop losing, and continue losing. The losing goes on and on so long you begin to watch with curiosity, wondering how low you can go" (98).

"Christmas" ends with the narrator still hoping to stop losing, but now more aware than ever that he is "a joke of a roofer, a joke of a roofer so beat down he once stood by watching as a nice man got cheated out of his Christmas" (99).

This moment is of the precise kind that inspired Toni Morrison's theory of an "Africanist" presence in American fiction. "I was interested," Morrison writes, "as I had been for a long time, in the way black people ignite critical moments of discovery or change or emphasis in literature not written by them" (viii). She argues, "Freedom (to move, to earn, to learn, to be allied with a powerful center, to narrate the world) can be relished more deeply in a cheek-by-jowl existence with the bound and unfree, the economically oppressed, the marginalized, the silenced" (64). Concerned as centrally as they are with questions of freedom and mobility, American workingclass representations would seem to be particularly susceptible to an invisible but palpable "Africanist" presence that defines the lack of freedom that forms the necessary conceptual 
background for representing white male freedom and autonomy. While "Christmas" conforms to Morrison's Africanist narrative strategy, it also seems reflexive about the very moves it makes, for instance, by admitting the perspective from which the narrator is a "Great White Dope."

Like the roofer in "Christmas," the "Sea Oak" narrator is tired of losing and desires to stop losing, but like many of Saunders's characters, he still cannot win. Well aware of the weights that hang upon him, the narrator is like a late-American Huckleberry Finn. ${ }^{3}$ If one were to look for Morrison's Africanist presence in "Sea Oak," this Huck Finn dimension of the story would be a good place to begin. Of Huckleberry Finn, Morrison writes, "Thus the fatal ending becomes the elaborate deferment of a necessary and necessarily unfree Africanist character's escape, because freedom has no meaning to Huck or to the text without the specter of enslavement, the anodyne to individualism; the yardstick of absolute power over the life of another; the signed, marked, informing, and mutating presence of a black slave" (56). The figure of Jim may be displaced in "Sea Oak," but the narrator's aspirations for autonomy and selfdetermination are underscored at all times by their abject opposite, which his own gendered experience of class keeps him just precariously above. When the narrator asserts, "If I had my way I'd move everybody up to Canada" (97), the patriarchal initiative of moving and protecting his family is rooted deeply in the image of the white male American and his differential ability "to move, to earn, to learn," as Morrison puts it.

At the same time, this frustration with and desire to leave America signals some crucial differences between the narrator of "Sea Oak" and Huck Finn. The narrator desires to escape, but unlike Huck, rather than to "light out" from the women he lives with, he wants to escape with them, even as he attempts to differentiate himself from the feminized position that he currently shares with them. He understands that everybody in his family is stuck. Also unlike Huckleberry Finn, part of the claim of "Sea Oak" is that there is no more American territory for which to light out. It is as though the old American dream has faded and its territories have been claimed by corporations. America seems at once saturated and exhausted, its landscape thoroughly suburbanized and commodified. Moreover, euphemisms like "Sea Oak" hide the real conditions of life in this landscape. For instance, one of the narrator's coworkers, Lloyd (even more emasculated than the narrator because he is rated a "Stinker" and fired), lives in "a sad little duplex on Self-Storage Parkway" (92). This wicked street name suggests that space is organized around corporate landmarks (like the view of FedEx from Sea Oak), and that Lloyd's and perhaps the narrator's lives can be depressingly reduced to the logistics of storage of their selves. Lives in "Sea Oak" are so diminished that they are simply stored in rooms by the highway, just as we store the necessary junk that we cannot throw away but prefer to keep out of sight.

\section{Scared to Life in a Crappy Apartment}

Throughout, the representation of class and material culture in "Sea Oak" is characteristically realistic, a realism that forms the context for Bernie's fantastic return. Consider, for example, the commercial breaks:

Min and Jade put down the babies and light cigarettes and pace the room while studying aloud for their GEDs. It doesn't look good. Jade says "regicide" is a virus. Min locates Biafra one planet from Saturn. . . .

They debate how many sides a triangle has. They agree that Churchill was in opera. Matt Merton comes back and explains that last week's show on suicide, in which the parents watched a reenactment of their son's suicide, was a healing 
process for the parents, then shows a video of the parents admitting it was a healing process. (93-94)

This passage could be a blueprint for Saunders's representational strategy in the early part of "Sea Oak." We are invited to laugh at Min's and Jade's realistic but wild misapprehensions and their hopeless ambition of preparing for their GED exams during commercials. While it is funny that the number of sides a triangle has should be matter for debate between Min and Jade, the obvious fact that at that rate they and their infant children will never break out of their futile routines is not. Saunders extends satirical realism to nearly every facet of the family's life, even to the kinds of food they eat:

For dinner Jade microwaves some Stars-n-Flags. They're addictive. They put sugar in the sauce and sugar in the meat nuggets. I think also caffeine. Someone told me the brown streaks in the Flags are caffeine. We have like five bowls each.

After dinner the babies get fussy and Min puts a mush of ice cream and Hershey's syrup in their bottles and we watch The Worst That Could Happen, a half-hour of computer simulations of tragedies that have never actually occurred but theoretically could. (107)

Here again we can recognize the mixed structure of naked realism and a satirical invitation to laugh. The absurdity of the unhealthy packaged food is matched only by the transparent appeal to consumption as patriotism ("Stars-n-Flags") and the realistic truth that the characters can both afford and choose it. When Aunt Bernie returns from the dead, one of her first acts is to tear the door off of the microwave.

Saunders subtly positions his reader as a consumer of working-class realist satire, setting him or her up for the intervention of Bernie's resurrection. As soon as we have laughed at Min and Jade, we have in effect become readers of their story who are similar to viewers of the television show they watch. How My Child Died Violently consoles its guests with the idea that they have been "sainted by pain," but this insincere compassion serves as the pretense for sensationalistic thrills at the suffering guests' expense. While Saunders models this grotesque form of entertainment by representing Min and Jade watching television, he also sets a trap for his readers by catching them in similar acts of being entertained. Without being detected, readers can take pleasure in the comical dimensions of characters stuck in vicious lives. Considering that all of the stories in Pastoralia originally appeared in The New Yorker, "Sea Oak" poses a selfreflexive class problem: is its largely middle-class readership so distant from the class about which Saunders writes that grotesque resurrections such as Bernie's could be real, but invisible to them? ${ }^{4}$

The terrible action of "Sea Oak" that changes the course of the plot and sets the stage for a new representational mode in the story is Aunt Bernie's "[death] of fright" (100). The terms with which Saunders describes Bernie's death and eventual resurrection are also highly realistic. Bernie is found still sitting on the couch, long after the burglar who scared her to death has absconded with her cash. The narrator eulogizes Bernie in his mind with characteristic directness:

I sit down beside Bernie. I think: I am so sorry. I'm sorry I wasn't here when it happened and sorry you never had any fun in your life and sorry I wasn't rich enough to move you somewhere safe. I remember when she was young and wore pink stretch pants and made us paper chains out of DrugTown receipts while singing "Froggie Went A-Courting." All her life she worked hard. She never hurt anybody. And now this. 
Scared to death in a crappy apartment. (100)

Saunders emphasizes that the ability to grieve is a class luxury. Before they can even begin to come to terms with their loss, they are faced with the realistic challenge of burying Bernie. This is not as easy as it might appear. Saunders underscores the class dimensions of death and dying in America when he depicts the family's negotiations at Lobton's Funeral Parlor. The scene represents a dialectic between cost and dignity:

"How much?" asks Jade. "I mean, like for basic. Not superfancy."

"But not crappy either," says Min. "Our aunt was the best." (101)

The realistic euphemisms of the marketplace extend into the funeral parlor. In their price range, the family is offered "Sierra Sunset," "Not exactly cardboard. More of a fiberboard" (101). Instructions printed on the box mention "Folding Tab A into Slot B" (102). Jade objects to burying Aunt Bernie in what amounts to a "Mayflower box," alluding to the packing materials of the eponymous moving company, but also ironically nodding toward America's origins. The higher-priced option is "Amber Mist," "which includes a double-thick balsa box and two coats of lacquer and a one-hour wake" (102). For dignity's sake, of course, there is only one choice. Bernie is buried in Amber Mist, and the family will pay for it in monthly installments spread out over seven years. She is interred "on the hill up near BastCo" (102), another corporate landmark. We may be consoled only by the fact that Bernie does not stay dead there for long.

\section{Uncoupled from the Actual}

In an essay on Kurt Vonnegut, Saunders articulates something that resembles his own method of exposing reality through postmodernist interventions in realist discourse. Saunders confesses that when he first read Slaughterhouse-Five, he was mortified when Vonnegut's Tralfamadorians intruded in the story. Nonetheless, Vonnegut seems to have taught Saunders that such unexpected interventions in realism are necessary if important experiences are to be conveyed to readers: "In fact, Slaughterhouse-Five seemed to be saying, our most profound experiences may require this artistic uncoupling from the actual" ("Mr. Vonnegut" 79). This "uncoupling from the actual" in order to represent the most profound experiences is a consistent feature of Saunders's fiction. The uncoupling often comes suddenly within a more or less realist (though almost always grotesque and satirical) context and often registers in the text as a comic shock. This is another narrative technique or effect that Saunders writes about in his Vonnegut essay: "Humor is what happens when we're told the truth quicker and more directly than we're used to. The comic is the truth stripped of the habitual, the cushioning, the easy consolation" (80). In this sense, the "actual" in Saunders is often the moment of comic shock that uncouples his text from the conventions of narrative realism and satire.

When Aunt Bernie is improbably resurrected, Saunders goes much further than merely modeling discourse and effects an ontological intervention in the story's, and our culture's, epistemologies of the working class. There is simply no place within any of the narrative conventions that Saunders has established for a working-class zombie to appear. The ontological rupture that results from Bernie's resurrection throws the satirical and realist modes into relief and questions their efficacy for depicting the lived conditions of the class they purport to represent. Bernie's zombie is in excess of the narrative system, just as the complex, differential experiences of the working class are in excess of the inadequate narrative strategies traditionally used to represent them.

Saunders adds a frightening tangibility to Bernie that makes her haunting all the more 
jarring. Nor is it in every sense her spirit, because her personality has radically changed, from patient and self-deceptive to urgent and overt. In this sense, her haunting of the others is not malevolent, in that Bernie tries to disrupt her family in order to impel it out of its vicious condition. Above all, however, to be haunted in "Sea Oak" is to be subject to fear, embarrassment, and anger over the lives of loved ones spent in squalor, danger, and denial. Bernie's decaying body comes back to live with the family as though she were alive. When the narrator is called home from work and finds Bernie in the rocking chair, the story shifts to a new register of uncertainty.

The resurrection forces us to think about the story we have been reading as a construct with certain rules and assumptions that have been at work within its representational modes. "Sea Oak" has foregrounded epistemological questions about the working class: How is it represented? How is it known? How does it know itself? It has explored the reaches of realism and comedy in order to exfoliate these epistemological matters. But as McHale writes, "Intractable epistemological uncertainty becomes at a certain point ontological plurality or instability: push epistemological questions far enough and they 'tip over' into ontological questions" (11).

The discursive terms of Bernie's resurrection include elements of reverse mourning, theological grotesquery, and morbid slapstick. Each of these dimensions of Bernie's representation helps to characterize the hitherto hidden suffering that Saunders's postmodernist intervention reveals about the working class. For instance, though Bernie returns to save the family, she also demonstrates a form of reverse mourning that suggests that the narrator, Min, and Jade are the true dead in the story. When she bites into a sandwich and "takes off the tip of her finger and starts chewing it up" (120), the action recalls the narrator's boss, who earlier in the story implored him "not to behave like one of those Comanche ladies who bite off their index fingers when a loved one dies" (111). Bernie, the dead, mourns for the living, who must, the logic runs, be pitiable even to the dead. In this way, Saunders plays upon the ontological uncertainty of Bernie's resurrection in order to figure her surviving family as the living dead. Saunders reveals more of this suffering by exploiting the inescapably religious overtones of resurrection. Bernie's resurrection concentrates a number of Christian elements that are dispersed through "Sea Oak," and Saunders represents it as a parody of Christian religious and theological discourses. As we have seen, the early portion of the story establishes Bernie's ideology of patient, saintly suffering, which has specifically Christian dimensions. Bernie comes back to prophesy Troy's death in cross fire if they stay at Sea Oak. She has a plan to save the family, which includes placing thumbprints on the foreheads of women who would be willing to pay the narrator extra to "show your cock" (115). ${ }^{5}$ Two thumbprints signify the woman's willingness to "screw you for cash" (121). Sure enough, at work the narrator sees a woman with the thumbprint, "Like Ash Wednesday, only sort of glowing" (116). Besides moving the family to a safer place and making them upwardly mobile (she has plans for the narrator to study pre-law), Bernie intends to bring them all to Rome, a place where the Virgin is worshipped. Bernie reveals that she "died a freaking virgin" (113).

All of these Christian elements combine in Bernie's resurrection to create a kind of theological grotesque, a parody that belies the ideology of patient suffering ("sainted by pain") to which Bernie subscribed during her life. The resurrected Bernie is insistent, even menacing: "I got powers!" (113). She is also highly libidinous: "Well I am going to have lovers now, you fucks!" (113). The promise of an afterlife and a heavenly reward is a cruel ruse: "You ever been in the grave? It sucks so bad! You regret all the things you never did" (115). Thus the theological 
grotesquery of "Sea Oak" exposes the complicity of religion in containing working-class discontent, for Bernie will no longer suppress her unfulfilled dreams and desires with patience and noble suffering. The theological grotesque also suggests that redemption must come during one's life and cannot be deferred. In fact, deferral equals certain death, at least for Troy: "Do you know what I'm doing for you? I'm saving your boy" (119). Here Bernie makes explicit her redemptive mission. Bernie's family needs to be saved; it will be redeemed not by Christ, but rather by a working-class zombie. The zombie at once parodies Christ's resurrection and reveals the hidden horror of a world that can be fully articulated only by making the zombie literal. Bernie embodies the living death of her entire family.

At the same time, Bernie's resurrection has a dimension of morbid slapstick that Saunders uses to extend his ontological revelations about the working class. ${ }^{6}$ As soon as she returns, Bernie's reanimated corpse begins to decompose and fall to pieces. Although first her ear and then her arm fall off, she is unapologetically oversexed and demands to try on Min's bras:

"I never had a nice sexy bra," says Bernie.

"And now mine are all ruined," says Min. "They got this sort of goo on them."

Such representations may crucially create an emotional response in readers that catches them between laughter and sadness, no more so than at the moment of Bernie's second and final death:

I rub her shoulder, which is next to her foot.

"We loved you," I say.

"Why do some people get everything and I got nothing?" she says. "Why? Why was that?"

"I don't know," I say.

"Show your cock," she says, and dies again. (123)

This moment may represent the culmination of grim humor in the story, and it is a moment of powerful affective potential. The passage telescopes matters of consolation, love, class inequality, and death in such a way that Saunders can pose the question of wealth distribution overtly and yet engage the reader's sympathies at the same time. When Bernie says, "Show your cock" here for the final time, a reader may be arrested between laughing and crying, or perhaps shocked into laughing and crying simultaneously. Have we been told a truth quicker and more directly than we are used to? The urgency of the class question that Bernie articulates combines with the sadness of her death, the dismembered state of her body, and the coarse and comic refrain about the narrator's cock in such a way that the potential response of simultaneous laughter and crying would reproduce on an emotional level the ontological disorientation that Saunders seeks to express through comic shock. This potential response accounts for a large part of the power and value of "Sea Oak," for it concentrates the grotesque pathos of Saunders's vision of class suffering in a moment of comic and shocking epiphany.

\section{Broadcasting Shame}

Through Bernie's resurrection, Saunders asks us to imagine that a terrible or even horrific sphere of reality exists that escapes our modes of representing and looking at social class, but which is no less real for our failures of apprehension. After Bernie dies a second time, the narrator packs her scattered remains into a Hefty bag and buries her. With the prophecy about Troy fixed in his mind, he resolves to move to a better apartment complex called Swan's Glen 
and to save five dollars out of every one hundred he earns, while prostituting himself on the side at Joysticks, to buy a gravestone for Bernie. It is after he finishes burying Bernie on the hill that he surveys the city and thinks, "I for sure don't plan on broadcasting this" (124). Once the grotesque and unexpected resurrection has occurred, we are forced to confront the narrator's suggestion - that perhaps this happens all the time - not as fantasy or illusion but as a potential dimension of the narrative's realism itself. The postmodernist ontological intervention is folded unsettlingly back onto the plane of realism. In this way, Saunders employs and deconstructs both representational techniques and their conservative or revolutionary "tendencies." Neither literary form triumphs over the other; rather, they stand in unsettling suspension or negation. Saunders thus evokes a whole category of experience that might remain hidden because it is too shameful or embarrassing to be broadcast.

What is the nature of this shame, and how does it relate to broadcasting class? How can we account for the narrator's apparently exceptional decision to write about his angry dead aunt when he imagines that so many like him have kept it secret? In Class Fictions, Pamela Fox builds upon Helen Merrell Lynd's mid-century On Shame and the Search for Identity, which describes how shame might be emancipatory. Paraphrasing Lynd, Fox writes:

The dual experiences of exposure and vulnerability, which are part and parcel of the shame dynamic, not only wound; they aid in the production of self-knowledge, community, and social critique. After suffering involuntary exposure, one can choose to expose that exposure, as it were, to another. ... Self awareness and confidence become possible because in the process of revealing the shame of being shamed, often one is exposing oppressive societal norms and values as well. ... Essentially serving a demystifying role, shame can thus function as a key to, rather than accomplice of, dominant ideology. (16)

Fox adopts much from this model-ideas of exposure, desire, and resistance-but her own model also "accommodates or allows for 'hegemonic' aspirations" (17). That is, in workingclass representations, there is often an urge to aspire to or meet the dominant class's expectations. Thus such narratives "move dialectically between the rejection of and longing for a more conventional narrative of identity and progress" (19).

Fox's dialectic of rejection and longing suggests a powerful way of thinking about the "Sea Oak" narrator. To write or broadcast his "shame of being shamed" is potentially emancipatory. Choosing to broadcast shame is a way of grasping power or agency from a situation in which he feels powerless. It also, following Lynd, allows him to expose the oppressive, and finally terrifying, societal norms that have produced the family's suffering. His "discovery" that there may be angry dead all over the homes of his class is a moment of class consciousness and the closest expression in the story to something like a collective identity or experience. At the same time, the very act of writing and the concomitant social aspirations that have emerged with the narrator's voice suggest that he is already aspiring toward bourgeois status. His articulation of his class experience is inseparable from his new program to transcend his class. "Sea Oak" associates the act of writing with both social power and class betrayal.

The claim itself - "I for sure don't plan on broadcasting this" - constitutes a stubborn contradiction. The narrator declares his intention not to broadcast his experience while at the same moment broadcasting exactly what he said he would not. "Sea Oak" thus develops an improvised form of representation as negation, or broadcasting as denial. This contradiction creates an intractable problem that leads to others, for his narrative seems not merely to report but also to form a part of his regimen of personal improvement. Here the logic of the story 
finally folds in upon itself: doesn't the narrator finally subscribe to Freddie's "bootstrap" philosophy of American personal responsibility and initiative, working hard in order to "move up to a somewhat less dangerous craphole" (106)? "Sea Oak" has painstakingly dismantled the bootstrap philosophy, only to have the narrator submit to it in the end, suggesting that the narrator may not fully understand the story he is telling. Or perhaps he understands it but sees no alternative to subscribing to the mythic hope of class mobility. A class will continue to be silently haunted by its angry dead, but the narrator will be a part of neither that silence nor, perhaps, that class. In fact, he will expose the fear and shame of his class on his way out of Sea Oak. For the narrator, this class experience is representable only in the attempt to leave it, through denial and negation, and from the gap or interstitial spaces between class identities when one is in the process of being traded for another.

The narrative seems to admit an anxiety about writing and class in which the exposure of the working class in stories, and perhaps even the narrative act itself, may be a kind of betrayal, a form of departing or distancing oneself from that class. Indeed, the narrator's new ambition to study the law may be seen as an attempt to master language as a form of power or control as much as it would represent a means of class mobility. A powerful ability to control language stands behind Saunders's own trajectory, as the son of a working-class father who sold coal to apartment buildings in Chicago who has become a celebrated figure in the academic creative writing establishment. ${ }^{7}$ As David Bahr notes in an interview with Saunders, the tension between writing and class is evident in accounts of his own experience: "Saunders says his father instilled in him a desire to write, but, coming from a working-class background, he never saw writing as a potential career" ("PW Interview" 322). Similarly, the "Sea Oak" narrator shifts from labor of the body to labor of the mind. As Bernie says, his body is all that he has to start with: "The world ain't giving away nice lives. You got a trust fund? You a genius? Show your cock. It's what you got" (122). There don't seem to be any routes of escape other than the one Bernie demands, except, of course, telling Bernie's story.

The narrator's power to broadcast or not to broadcast is thematized near the very end of the story, when he contemplates what he will write on Bernie's headstone once he saves enough to buy it. Again, what one writes or does not write is the crucial question:

What do you write on something like that? LIFE PASSED HER BY? DIED DISAPPOINTED? CAME BACK TO LIFE BUT FELL APART? All true, but too sad, and no way I'm writing any of those.

BERNIE KOWALSKI, it's going to say: BELOVED AUNT. (125)

This is an example of what rhetoricians call "apophasis," a way of speaking of something through the very act of denying that one will speak of it. The narrator says that he will not inscribe Bernie in these ways, but by saying that he will not, he does.

We might extend the scope of this apophasis to encompass larger portions of the story as well. For all of "Sea Oak" may be seen as an inscription of Bernie, and in the course of it, the narrator has in fact written or published what he says he will not publish on her stone. In other words, he has asserted that her life passed her by, that she died disappointed, and that she came back to life but fell apart. This suggests that it is perhaps only by denial and negation that this experience of class, gender, sexuality, and race can be broadcast. If fixed senses and traditional representations of class have tended to belie working-class experience, it is because such visions cannot account for the complexity of individual and collective identity, which is often fractious, contradictory, or even paradoxical. In response, Saunders articulates his characters' experiences from the very location of these fractures, contradictions, and paradoxes. In this way, Saunders's 
fiction reflects and responds to the state of current theory regarding class as a differential category and suggests a way of moving beyond the formal impasse for representing these complexities by setting up the tendencies of realism and postmodernism to shock one another.

\section{Notes}

1. McHale argues that "the dominant of postmodernist fiction is ontological" and follows Dick Higgins in foregrounding questions such as "What world is this? What is to be done in it? Which of my selves is to do it?" (qtd. in McHale 10), as well as "What kinds of world are there, how are they constituted, and how do they differ?; What happens when different kinds of world are placed in confrontation, or when boundaries between worlds are violated?" (10).

2. Saunders emphasizes financial constraints by supplying concrete detail about the narrator's income: "I Pilot six tables and make forty dollars in tips plus five an hour in salary" (92). If we imagine that his shift is from 6 p.m. to midnight, then he averages one table per hour, with an average tip of $\$ 6.67$. If he also makes five dollars per hour, he would have added thirty dollars to his tips, for a total of about seventy dollars for a night's work. If that night is fairly representative, and he works six nights per week, he would earn less than $\$ 22,000$ per year, before taxes. According to the United States Department of Health and Human Services, the poverty threshold was just under $\$ 23,000$ in 2000 for a six-person family ("2000 HHS Poverty Guidelines"). Even if he worked every night of the year, the narrator's income would amount to little more than $\$ 25,000$ before taxes. Bernie has been demoted from Cashier to Greeter after fifteen years at DrugTown and makes minimum wage. In 2000, the federal minimum wage was $\$ 5.15$ ("History of Federal Minimum Wage Rates"). If Bernie works at DrugTown for forty hours per week, her yearly income would be below $\$ 11,000$. These are obviously inexact calculations based on general guidelines and internal textual evidence, but Saunders gives enough detail for us to understand that this family hovers precariously above the poverty line.

3. Saunders has written an introduction to Huckleberry Finn. It is collected in The Braindead Megaphone: Essays.

4. The Complete New Yorker DVD archive contains an unusual list of "keywords" for the story that demonstrate its bizarre range: Death; Burlesque; Canada; Babies; Aunts; Guns; Funerals; Science Fiction; Nightclubs; Zombies; Poor People; Strip Tease (Male).

5. "Show your cock" is one of the frequent refrains of "Sea Oak," alerting us to the potential pun in the title that may suggest "see wood," that is, an erect penis.

6. Bernie's name may evoke another morbid slapstick source, the 1989 comedy Weekend at Bernie's. At the beginning of this movie, two corporate climbers discover their boss, Bernie Lomax, murdered in his beach house. In order to survive the weekend without being murdered themselves, and also to preserve their corporate dreams, the two tote around Bernie's corpse in various improbable and increasingly grotesque situations, convincing others with surprising ease that Bernie is in fact alive. Whether or not Saunders deliberately alludes to Weekend at Bernie's, much of his treatment of Bernie's resurrected corpse in "Sea Oak" has affinities to the morbid comedic mode of that film. 
7. Saunders's position in the creative writing establishment is briefly discussed by Mark McGurl.

\section{Works Cited}

"The 2000 HHS Poverty Guidelines." United States Department of Health and Human Services. 16 Dec. 2005. Web. 2 May 2009.

Dimock, Wai Chee, and Michael T. Gilmore. Introduction. Rethinking Class: Literary Studies and Social Formations. New York: Columbia UP, 1994. 1-11.

Foley, Barbara. Radical Representations: Politics and Form in U.S. Proletarian Fiction, 19291941. Durham, NC: Duke UP, 1993.

Fox, Pamela. Class Fictions: Shame and Resistance in the British Working-Class Novel, 18901945. Durham, NC: Duke UP, 1994.

"History of Federal Minimum Wage Rates under the Fair Labor Standards Act, 1938-2007." United States Department of Labor. Web. 2 May 2009.

Kaplan, Cora. "Introduction: Millennial Class." PMLA 115.1 (2000): 9-19.

Lukács, Georg. Realism in Our Time. Trans. John Mander and Necke Mander. New York: Harper, 1964.

Lynd, Helen Merrell. On Shame and the Search for Identity. New York: Science Editions, 1958.

McGurl, Mark. The Program Era: Postwar Fiction and the Rise of Creative Writing. Cambridge, MA: Harvard UP, 2009.

McHale, Brian. Postmodernist Fiction. New York: Methuen, 1987.

Morrison, Toni. Playing in the Dark: Whiteness and the Literary Imagination. Cambridge, MA: Harvard UP, 1992.

Saunders, George. The Braindead Megaphone: Essays. New York: Riverhead, 2007.

---. "Christmas." In Persuasion Nation. New York: Riverhead, 2006. 89-99.

---. "Mr. Vonnegut in Sumatra." Saunders, Braindead Megaphone 73-83.

---. "PW Interview: George Saunders, Oppressing the Comfortable." Conducted by David Bahr. Publishers Weekly 14 Aug. 2000: 322-23.

---. “Sea Oak.” New Yorker 28 Dec. 1998: 112-23. The Complete New Yorker. New York: New Yorker, 2005. DVD-ROM. 8 discs.

---. “Sea Oak." Pastoralia. New York: Riverhead, 2000. 91-125.

---. "The United States of Huck." Saunders, Braindead Megaphone 187-210.

Thompson, E. P. The Making of the English Working Class. New York: Pantheon, 1963.

Weekend at Bernie's. Dir. Ted Kotcheff. Perf. Andrew McCarthy, Jonathan Silverman, Catherine Mary Stewart, and Terry Kiser. Twentieth Century Fox, 1989. Film. 